DOI 10.7251/SCMED1802099C UDC 616.33-005.1-089.87 COBISS.RS-ID 7836952

\title{
Importance of Selection a Method of Reconstruction of Digestive Continuity After Gastrectomy
}

\begin{abstract}
Introduction: Gastrectomy is one of the most common surgical methods for the treatment of gastric cancer, which basically destroys the mechanism and digestion chemistry. Reconstruction after gastrectomy attempts to optimize the antireflux and nutritive component of the postgastrectomic syndrome.
\end{abstract}

Objective: To determine which reconstructive method after gastrectomy has the optimal synthesis of antireflux and nutritional components.

Patients and Methods: 111 patients were treated for gastric malignancies at the Surgical Clinic of the University Clinical Center in Banja Luka, which were operated with the intention of achieving curability.

Results: Based on Fisher's exact probability test there is no statistically significant difference ( $p>0.05$ ) in mortality compared to the restoration of digestive continuity after gastrectomy. Reflux oesophagitis is the dominant modality of morbidity in omega-loop reconstruction $(p<0.05)$. There is no statistically significant difference ( $p>0.05$ ) in late dumping syndrome in patients relative to individual gastric substitution options. In the Hunt-Lawrence-Rodino pouch reconstruction option, there is no statistically significant difference ( $p>0.05$ ) in the participation of individual modalities of meal quantity in relation to the condition before the disease or the modality of the nutritional status. .

Conclusion: The results indicate the antireflux component of reconstruction Roux en $Y$ and the advantage of the nutritive component in the loop modification (the creation of the Hunt-Lawrence-Rodino pouch).

Key words: gastric cancer, gastrectomy, methods of reconstruction, postoperative morbidity
Jovan Ćulum', Nebojša Trkulja ${ }^{3}$, Dmitar Travarn, Zoran Aničić ${ }^{2}$, Jugoslav Đeri ${ }^{2}$, Goran Janjicí ${ }^{2}$, Velimir Škrbić ${ }^{2}$, Aleksandar Guzijan 4 , Davor Grahovac 4

${ }^{1}$ Clinic "S-tetik" Banja Luka, RS, BiH, Faculty of Medicine, University of Banja Luka, Banja Luka, Republic of Srpska, Bosnia and Herzegovina

${ }^{2}$ Clinic for General and Abdominal Surgery, University Clinical Center of the Republic of Srpska, Banja Luka, RS, BiH, Faculty of Medicine, University of Banja Luka, Banja Luka, Republic of Srpska, Bosnia and Herzegovina

${ }^{3}$ Clinic for General and Abdominal Surgery, University Clinical Center of the Republic of Srpska, Banja Luka, RS, BiH

${ }^{4}$ Mammal center, University Clinical Center of the Republic of Srpska, Banja Luka, RS, BiH, Faculty of Medicine, University of Banja Luka, Banja Luka, Republic of Srpska, Bosnia and Herzegovina

${ }^{5}$ Clinic for Otorhinolaryngology, University Clinical Center of the Republic of Srpska, Banja Luka, RS, BiH, Faculty of Medicine, University of Banja Luka, Banja Luka, Republic of Srpska, Bosnia and Herzegovina

Corresponding author: Jovan Ćulum

e-mail: culumj1961@gmail.com

Manuscript received: July $9^{\text {th }}, 2018$

Manuscript accepted:

November $7^{\text {th }}, 2018$ 


\section{Introduction}

Stomach cancer is one of the common visceral neoplasms around the world although with decreasing trend. As gastric malignant surgery is a highly mutilatory operative procedure that substantially changes the mechanism of digestion, the need for finding a modality of digestive tube reconstruction has been imposed which will replacement is the most optimal. Correction of the damaged mechanical component of the digestion is in the focus of the surgeon's interest, while humoral and neural alterations are in the domain of interest of endocrinologists and gastroenterologists. ${ }^{1-7}$

\section{Objective}

To determine whether the construction of the gastric reservoir increases the rate of mortality and morbidity operated by gastric malignancies and assess whether the construction of the gastric reservoir has a satisfactory antireflux and nutritional component.

\section{Patients an Methods}

The base of the study is represented by 211 patients who have been operated for stomach malignancies at the Clinical Center Banja Luka in the period from 2002 to 2012 and monitored for 5 years after surgery, and the subject of a detailed analysis is 111 patients who were operated with the intention of achieving curability. The quality of life was tested $6,12,24$ and 60 months after surgery. The paper used the documentation of the Surgical Clinic, the Oncology Clinic, and the Pathology Institute of the Clinical Center in Banja Luka. Classification of patients was done on the basis of sex and age, and malignancies of the stomach based on macroscopic and microscopic appearance, tumor location and stage of the disease. Men were 64 or $57.7 \%$, and women 47 or $42.3 \%$. The lifespan was $60-70$ years (36\%), adenocarcinoma was 92\%, lymphoma $5 \%$ and sarcoma $3 \%$. Limited extensibility options were $5 \%, 43 \%$ of subtotal resections, $46 \%$ of total gastrectomy and $6 \%$ of extensive total gastrectomy were done. In $52.63 \%$ of gastrectomed patients, the reconstruction was done with the RY method, $43.86 \%$ was made with a gastric reservoir (HLR), and in 2 patients (3.51\%), a reconstruction of the omega loop was performed.

\section{Results}

\section{Mortality}

Postoperative mortality was tested (30 days after surgery). From 111 operated with the intention of achieving radical surgery six patients died (5.41\%); one patient with reconstruction omega loop, two patients with RY reconstruction and three with reconstruction HLR reservoir. Based on the Fisher's exact test probability ( $p=$ 0.295 ), there was no statistically significant difference ( $p>$ 0.05) in mortality compared to the option of restoration of digestive continuity after gastrectomy.

\section{The frequency of heartburn}

Medical history was tested operated on the basis of the survey questionnaire within the Index of quality of life by Eypasch, Williams and Troidl-in of the 36 questions (Gastrointestinal Quality of Life Index- GIQLI).

Chart 1. The frequency of heartburn

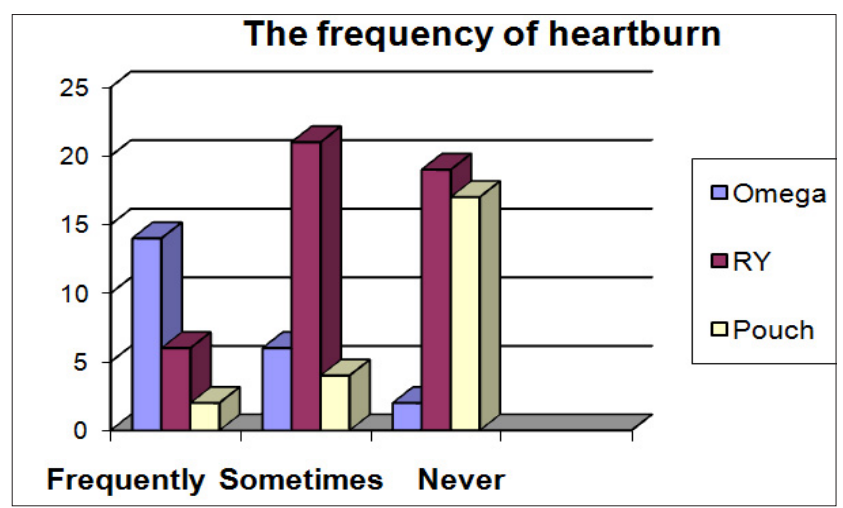

Based on the calculated value of the test of the assumed proportions for the option of reconstructing the omega loop $(\mathrm{z}=2.659 ; \mathrm{p}=0.0078)$, there was a statistically significant difference $(\mathrm{p}<0.01)$ in the participation of patients who had frequent heartburn. With the Roux en Y reconstruction option $\left(\mathbf{X}^{2}=8.652 ; \mathrm{p}=0.0132\right)$, there is a statistically significant difference $(\mathrm{p}<0.05)$ in the participation of patients who have sometimes had a heartburn. In the Hunt-Lawrence-Rodino pouch reconstruction option $(\mathrm{z}=5.223 ; \mathrm{p}=0.0000)$ there is a statistically significant difference $(p<0.01)$ in the participation of a group of patients who have never had a heartburn. (Chart 1).

\section{Reflux gastritis and oesophagitis}

Endoscopic diagnosis was performed after 6 and 12 months of operation. Based on the calculated value of Fischer's test (Fischer: $\mathrm{p}=0.030$ ), in the total sample analyzed, there is a statistically significant difference ( $p<0.05$ ) in the occurrence of reflux gastritis and oesophagitis in patients with respect to certain gastric substitution options, with dominant modality reflux I degree. Among the different modes of reflux, the II and III degrees of reflux are significant in the reconstruction of omega-loop. 


\section{Dumping syndrome}

Dumping syndrome is manifested by vasomotor symptoms, such as: diarrhoea, weakness, trembling, cold sweating, palpitations. Early dumping can be manifested by gastrointestinal symptoms, such as: feeling fullness in the abdomen, abdominal pain, torment, vomiting and explosive diarrhea. We tested an early dumping syndrome (by glucose-Sigstad test) and most patients did not show signs of a serious dumping syndrome.

Based on the calculated value of $\mathrm{X}^{2}$ test $\left(\mathrm{X}^{2}=1.000\right.$; $\mathrm{p}=0.9098$ ), based on the formed contingency table, there is no statistically significant difference in the total sample ( $>$ > 0.05) in early dumping syndrome in patients compared to individual gastric substitution options.

\section{Quantity of meals}

The quantity of the meal was tested with a questionnaire on the quantity of meals in relation to the condition before the disease (the same, less, much less). There is a statistically significant difference $(\mathrm{p}<0.05)$ in the option of reconstruction of the omega loop $\left(\mathrm{X}^{2}=9.091 ; \mathrm{p}=\right.$ 0.0106) in the participation of individual modality of the quantity of meals, with the dominance of those patients who take quantitatively smaller rations compared to the condition before the onset of the disease. In the case of the reconstruction option Roux en $\mathrm{Y}(\mathrm{z}=5.032 ; \mathrm{p}=$ $0.0000)$ there is a statistically significant difference ( $p$ $<0.01$ ) in the participation of individual modalities of meal quantity, with the dominance of those who take quantitatively much smaller rations compared to the condition before the onset of the disease. There is no statistically significant difference ( $p>0.05$ ) in the case of the reconstruction of the Hunt-Lawrence-Rodino pouch $\left(\mathrm{X}^{2}=3.217 ; \mathrm{p}=0.2002\right)$ in the participation of individual modalities of meal quantity in relation to the condition before the disease.

\section{Food Transit}

The food transit was made on a gamma camera using radiofarm (isotope) Tc99m -sulphur colloid in a dose of 2-3 mCi (74-111 kBq). A comparison was made between the RY reconstruction and reconstruction options HuntLawrence-Rodino pouch. With the Roux en Y method, rapid discharge of foods labeled with radioactive Tc99 was registered. After 30 minutes, only about $30 \%$ of the total amount of food was registered in the Roux loop region, after about 45 minutes, about $18 \%$, and after 60 minutes, signs of radioactivity (about 10\%) were barely displayed. When reconstructing the HLR reservoir after 30 minutes, over $60 \%$ of the total amount of food is registered in the reservoir, and after about 60 minutes about $35 \%$. And after two hours, the artifical stomach showed signs of radioactivity (about $10 \%$ of the total volume) (Chart 2).

\section{Chart 2. Food Transit}

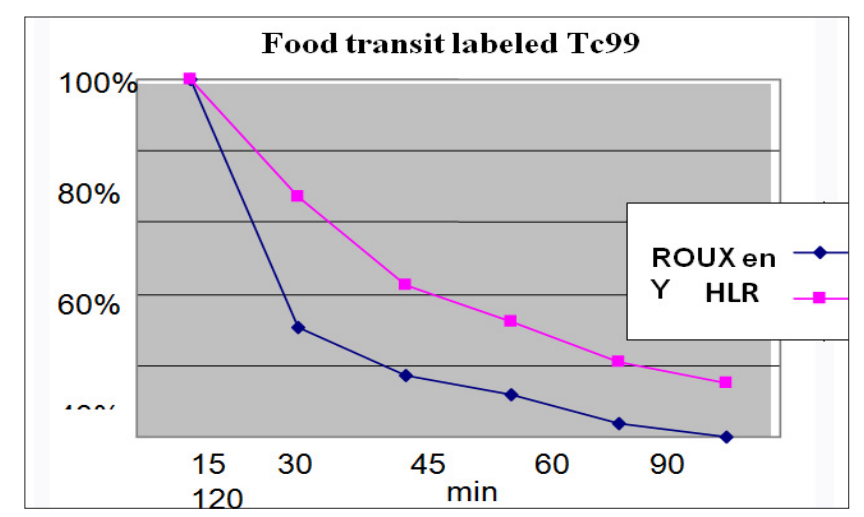

\section{Malnutrition}

Under moderate malnutrition, a loss of up to $5 \mathrm{~kg}$ of preoperative body weight is assumed, medium severe malnutrition, a loss of 5-10 kg of body weight is implied, and loss of more than $10 \mathrm{~kg}$ of preoperative body weight is considered to be severe malnutrition. There is no statistically significant difference ( $p>0.05$ ) in the involvement of individual modalities of malnutrition in the omega-reconstruction option $\left(\mathrm{X}^{2}=0.400 ; \mathrm{p}=\right.$ o.8187). In the case of the reconstruction option Roux en $\mathrm{Y}\left(\mathrm{X}^{2}=18.059 ; \mathrm{p}=0.0001\right)$ there is a statistically significant difference $(\mathrm{p}<0.01)$ in the interaction between particular modalities of malnutrition, with the dominant mode of moderate malnutrition. There is no statistically significant difference ( $p>0.05)$ in the participation of individual modalities of malnutrition in the case of the reconstruction of digestion continuity Hunt-LawrenceRodino pouch $(\mathrm{z}=0.000 ; \mathrm{p}=1.0000)$.

\section{Nutritional status - (Blackburn)}

The relationship between current and preoperative body weight (Blackburn) served to evaluate the postoperative nutritional status of the patient. It was used in the following way:

1. Blackburn <1 ---- malnutrition;

2. Blackburn 1-1.2 - optimum nutrition;

3. Blackburn $>1,2$ - adiposity.

Based on the calculated value of the test of the assumed proportions for the omega loop reconstruction option (z $=3.662 ; \mathrm{p}=0.0003$ ), there is a statistically significant difference $(p<0.01)$ in the participation of the Blackburn 
nutritional status modality $<1$. In the case of the reconstruction option Roux en $\mathrm{Y}(\mathrm{z}=7.388$; $\mathrm{p}=0.0000)$ there is a statistically significant difference $(p<0.01)$ in the participation of the Blackburn nutritional status modality $<1$. At Hunt-Lawrence-Rodino pouch reconstruction ( $\mathrm{z}$ $=1.262 ; \mathrm{p}=0.2069)$ there is no statistically significant difference ( $p>0.05)$ in the participation of certain modalities of nutritive status (Chart 3).

\section{Chart 3. Nutritional status - (Blackburn)}

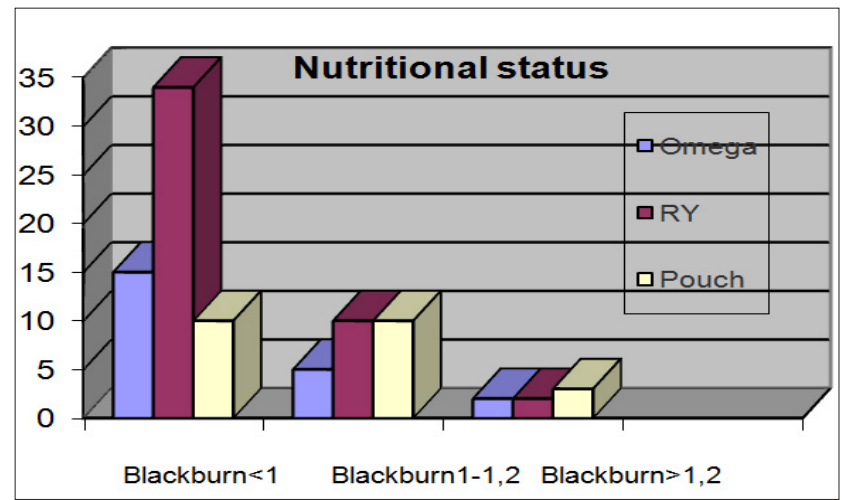

\section{Discussion}

Extensive surgery of visceral malignancy, as well as various modalities of oncological treatment, have prolonged the lifespan of the patients. As certain options of gastrointestinal continuity reconstruction have a different effect on the reduction of the intensity of postgastrectomy sequela, the problem of the importance of selecting digestive reconstruction after the surgical treatment of gastric malignancies has been imposed. The dominant sequences of postgastrectomy syndrome are, of course, alkaline reflux and nutritional deficiency. The incidence of heartburn was dominant in the omega loop option, while in the reconstruction of the reservoir they were registered in one-fifth of the patients. Reflux gastritis and oesophagitis is a sequela that is registered in $28.3 \%$ of the operatives, and this is dominant in the option of reconstructing the digestive tract with omegaloop. The late dumping syndrome was registered in $24,17 \%$ of the observed, dominant total gastrectomy. There was no statistically significant difference in relation to individual methods of reconstruction. Early dumping syndrome was tested according to Sigstad (a glucose load test) and was recorded in one third of the patients. Serious problems are registered predominantly in total gastrectomy, and among some reconstructive options, the occurrence of moderate and mild problems in the method of reconstruction by omega loop is more frequent. In several series analyzing the quality of life after gastric replacement, the authors find the highest incidence of heartburn after reconstruction without a reservoir, which is confirmed by the endoscopic finding of reflux oesophagitis. A similar finding was found in the quantification of the severity of the postprandial dumping syndrome with the dominant symptomatics in patients who underwent reconstruction without a reservoir. The frequency of daily food rations was greatest in gastric replacement options with the Hunt-Lawrence-Rodine reservoir, and the quantity of meals was slightly higher in the same option for the reconstruction of digestive continuity (Hunt-Lawrence-Rodino). Nutritional status was assessed based on the current and optimal weight ratio (Blackburn) and the best result was registered with the reconstruction option with the reservoir. Visick grade, Karnofsky index of general physical abilities, Spitzer index, Troidl scoring system parameters were used which indicate optimal postoperative results achieved by creation of a gastric reservoir that has antireflux and nutritive component..$^{1-6}$

Analyzing the quality of life after some options of surgical reconstruction of digestive continuity, data on postoperative malnutrition caused by a loss of body weight over $5 \mathrm{~kg}$ in the three-month period are predominant after total gastrectomy and gastric substitution with the reservoir. Analyzing dietary restrictions that lead to weight loss, it can be concluded that there is no statistically significant difference in nutritional value after 3, 6, and 12 months in some modes of digestive continuity reconstruction..$^{-10}$

In several series, authors evaluate the quality of life for certain gastric substitution options and come up with similar results: patients with omega-loop (Brown) had a heartburn, and endoscopically confirmed reflux esophagitis stage I or II. In a patient in whom a conversion of omega loop was performed in the antireflux Roux en $\mathrm{Y}$ option (Schloffer reconstruction), a complete remission of the disorder occurred. After reoperation, patients achieved approximately preoperative body weight. The authors conclude that total gastrectomy should not be avoided because of the fear of developing postoperative progressive malnutrition. A simple Roux en Y option without a reservoir design is a satisfactory option for reconstructing the digestive tract after gastrectomy, and the issue of creating an artificial reservoir remains open. Creation of omega loop does not prevent the occurrence of reflux oesophagitis and should be avoided. The Cuschier scoring system points to the simple Roux en Y option and Roux en Y with the reservoir (Hunt-Lawrence-Rodino) as the optimal nutritional and antireflux options for gastric replacement. ${ }^{11-16}$

In the analyzed sample of patients undergoing surgery, 
compared to the frequency of daily meals tested after $6,12,24,60$ months after surgery, there is a significant difference in individual reconstruction options. The method of reconstruction of the reservoir is dominated by the participation of the modalities of less than 4 meals a day, and with Roux en $\mathrm{Y}$ reconstructive methods the modality of more than 6 meals a day is most present. The quantity of the largest meal was taken by patients in whom the reconstruction of the reservoir was done, where one third gave data about approximately the same amount of foods for each meal as before the operation. After 30 minutes, only about $30 \%$ of all foods were registered in Roux loop, after about 45 minutes, about 18\%, and after about 60 minutes about $10 \%$. When reconstructing the reservoir, after 30 minutes over $60 \%$ of the total amount of food is registered in the reservoir, and after 60 minutes about $35 \%$. And after two hours, the artifical stomach showed signs of radioactivity (about 10\% of the total volume). Comparing the rate of discharge of food from the artificial gaster (gastric pouch) and simple Roux en $\mathrm{Y}$ reconstruction methods, the authors have come up with results that show that Roux en Y methods were the rapid discharge of foods labeled with radioactive Tc99, which is a common cause of dumping syndrome and postoperative malnutrition..$^{1-22}$

In the overall sample analyzed, about two-thirds failed to reach preoperative body weight, and statistically significant is the equal participation of all nutritient status modes in the reservoir reconstruction option. The option of gastric substitution by omega loop in a significant percentage causes the occurrence of gastritis and oesophagitis reflux which is the dominant component of the postgastrectomic syndrome. The obtained results of the quality of life assessment are comparable with the results of other statistical series. They confirm the antireflux component Roux en Y loop and its intestinoplasty and emphasize the advantage of the nutritional component of the loop modification (creations of the pouch).

\section{Conclusion}

Reflux of biliopancreatic content adequately prevents Roux en $\mathrm{Y}$ loop from the restoration of digestive continuity, but its nutritional component is insufficient. Improvement of the nutritional component Roux en $\mathrm{Y}$ reconstruction method can be achieved by intestinoplasty of the drainage (loop modification), but the issue of satisfactory correction of malnutrition remains unresolved. The option of gastric substitution by the reservoir reduces the level of restriction of the food comfort caused by the loss of the stomach as a food reservoir (it allows for the taking of a quantity of meal volume and reduces the daily number of meals), while slowing the transit of food reduces the incidence of the emergence of a dumping syndrome.

\section{References}

1. Coburn N, Seevaratnam R, Paszat L, Helyer L, Law C, Swallow $\mathrm{C}$, et al. Optimal management of gastric cancer: results from an international RAND/UCLA expert panel. Ann Surg 2014;259:102-8.

2. Bo T, Peiwu Y, Feng Q, Yongliang Z, Yan S, Yingxue H, et al. Laparoscopy-assisted vs. open total gastrectomy for advanced gastric cancer: long-term outcomes and technical aspects of a case-control study. J Gastrointest Surg 2013;17:1202-8.

3. Shin D, Park SS. Clinical importance and surgical decisionmaking regarding proximal resection margin for gastric cancer. World J Gastrointest Oncol 2013;5:4-11.

4. Squires MH 3rd, Kooby DA, Poultsides GA, Pawlik TM, Weber SM, Schmidt CR, et al. Is it time to abandon the 5 - $\mathrm{cm}$ margin rule during resection of distal gastric adenocarcinoma? A multi-institution study of the U.S. Gastric Cancer Collaborative. Ann Surg Oncol 2015;22:1243-51.

5. Brar S, Law C, McLeod R, Helyer L, Swallow C, Paszat L, et al. Defining surgical quality in gastric cancer: a RAND/ UCLA appropriateness study. J Am Coll Surg 2013;217:34757.

6. Hirao $\mathrm{M}$, Takiguchi $\mathrm{S}$, Imamura $\mathrm{H}$, Yamamoto $\mathrm{K}$, Kurokawa Y, Fujita J, et al. Comparison of Billroth I and Roux-en-Y reconstruction after distal gastrectomy for gastric cancer: one-year postoperative effects assessed by a multi-institutional RCT. Ann Surg Oncol 2013;20:1591-7.

7. Kurita N, Miyata H, Gotoh M, Shimada M, Imura S, Kimura W, et al. Risk Model for Distal Gastrectomy When Treating Gastric Cancer on the Basis of Data From 33,917 Japanese Patients Collected Using a Nationwide Web-based Data Entry System. Ann Surg 2015;262:295-303.

8. Avery K, Hughes R, McNair A, Alderson D, Barham P, Blazeby J. Health-related quality of life and survival in the 2 years after surgery for gastric cancer. Eur J Surg Oncol. 2010;36(2):148-54.

9. Karanicolas PJ, Bickenbach K, Jayaraman S, Pusic AL, Coit DG, Guyatt GH, et al. Measurement and interpretation of patient-reported outcomes in surgery: an opportunity for improvement. J Gastrointest Surg 2011;15(4):682-9.

10. King MT, Fayers PM. Making quality-of-life results more meaningful for clinicians. Lancet 2008;371:709-10.

11. Kobayashi D, Kodera Y, Fujiwara M, Koike M, Nakayama G, Nakao A. Assessment of quality of life after gastrectomy using EORTC QLQ-C3O and STO22. World J Surg 2011;35(2):357-64.

12. Lee SS, Chung HY, Yu W. Quality of life of long-term survivors after a distal subtotal gastrectomy. Cancer Res Treat 2010;42(3):130-4.

13. Nakamura M, Hosoya Y, Yano M, Doki Y, Miyashiro I, 
Kurashina K, et al. Extent of gastric resection impacts patient quality of life: the Dysfunction After Upper Gastrointestinal Surgery for Cancer (DAUGS32) scoring system. Ann Surg Oncol 2011;18(2):314-20.

14. Vickery CW, Blazeby JM, Conroy T, Arraras J, Sezer O, Koller M, et al. Development of an EORTC disease-specific quality of life module for use in patients with gastric cancer. Eur J Cancer 2001;37(8):966-71.

15. Eypasch E, Williams JI, Wood-Dauphinee S, Ure BM, Schmulling C, Neugebauer E, Troidl H. Gastrointestinal Quality of Life Index: development, validation and application of a new instrument. Br J Surg 1995;82:21622.

16. Cella DF, Tulsky DS, Gray G, Sarafian B, Linn E, Bonomi A, et al. The functional assessment of cancer therapy scale: development and validation of the general measure. J Clin Oncol 1993;11:570-579.

17. McCall MD, Graham PJ, Bathe OF. Quality of life: a critical outcome for all surgical treatments of gastric cancer. World J Gastroenterol 2016;22(3):1101-13.

18. Climent M, Munarriz M, Blazeby JM, Dorcaratto D, Ramon
JM, Carrera MJ. Weight loss and quality of life in patients surviving 2 years after gastric cancer resection. Eur J Surg Oncol 2017;43(7):1337-43.

19. Munene G, Francis W, Garland SN, Pelletier G, Mac KLA, Bathe OF. The quality of life trajectory of resected gastric cancer. J Surg Oncol 2012;105:337-41.

20. Watanabe M, Mine S, Nishida K, Kurogochi T, Okamura A, Imamura Y. Reconstruction after esophagectomy for esophageal cancer patients with a history of gastrectomy. Gen Thorac Cardiovasc Surg 2016;64(8):457-63.

21. Nakamura M, Hosoya Y, Umeshita K, Yano M, Doki Y, Miyashiro I, et al. Postoperative quality of life: development and validation of the "Dysfunction After Upper Gastrointestinal Surgery" scoring system. J Am Coll Surg 2011;213:508-14.

22. Takiguchi S, Yamamoto K, Hirao M, Imamura H, Fujita $\mathrm{J}$, Yano $\mathrm{M}$, et al. A comparison of postoperative quality of life and dysfunction after Billroth I and Roux-en-Y reconstruction following distal gastrectomy for gastric cancer: results from a multi-institutional RCT. Gastric Cancer 2012;15(2):198-205.

\section{Značaj izbora metode rekonstrukcije digestivnog kontinuiteta nakon gastrektomije}

\section{SAŽETAK}

Uvod: Gastrektomija je jedna od najčešćih hirurških metoda liječenja karcinoma želuca koja u osnovi narušava mehanizam i hemizam probave. Rekonstrukcijom nakon gastrektomije pokušava se optimizirati antirefluksna i nutritivna komponenta postgastrektomijskog sindroma.

Cilj rada: Utvrditi koja metoda rekonstrukcije nakon gastrektomije ima optimalnu sintezu antirefluksne i nutritivne komponente.

Pacijenti i metode: Analizirano je 111 pacijenata operisanih zbog malignoma želuca na Hirurškoj klinici Univerzitetskog Kliničkog centra u Banjaluci koji su operisani sa namjerom postizanja kurabilnosti.

Rezultati: Na osnovu Fisher-ovog testa egzaktne vjerovatnoće ne postoji statistički značajna razlika (p>0,05) u mortalitetu u odnosu na opciju restauracije digestivnog kontinuiteta nakon gastrektomije. Refluks ezofagitis je dominantni modalitet morbiditeta kod rekonstrukcije omega vijugom $(p<0,05)$. Nema statistički značajne razlike $(p>0,05) u$ kasnom dumping sindromu kod pacijenata u odnosu na pojedine opcije želučane supstitucije. Kod opcije rekonstrukcije Hunt-Lawrence-Rodino pouch ne postoji statistički značajna razlika $(p>0,05)$ u učešću pojedinih modaliteta kvantiteta obroka u odnosu na stanje prije bolesti niti modaliteta nutritivnog statusa.

Zaključak: Rezultati ukazuju na antirefluksnu komponentu rekonstrukcije Roux en Y i prednost nutritivne komponente kod loop modifikacije (kreacije Hunt-Lawrence-Rodino pouch-a).

Ključne riječi: karcinom želuca, gastrektomija, metode rekonstrukcije, postoperativni morbiditet 